\title{
Monitoring of Afforestation Activities Using Landsat-8 Temporal Images, Billion Trees Afforestation Project, Pakistan
}

\author{
Muhammad Daud Khan, Anwar Ali, Arif Iqbal, Zia-ur-Rehman, Waqar Ahmed, Saba Ali \\ Arooj
}

\begin{abstract}
Nacrtak
In context of Bonn Challenge commitment, Pakistan (Khyber Pukhtunkhwa) has implemented forest restoration and afforestation on 0.35 million hectares between 2015-2017. Billion Tree Afforestation Project (BTAP) is an initiative of mass afforestation and forest restoration to meet the Bonn Challenge commitment. The current study is a pilot study to evaluate the success of plantation activities by assessment of regeneration, growth performance and survival rate of plantations raised under BTAP in Malakand Forest Division. Further, four vegetation indices were computed from Landsat-8 image, which include Normalized Difference Vegetation Index (NDVI), Soil Adjusted Vegetation Index (SAVI), Modified Soil Adjusted Vegetation Index (MSAVI) and Difference Vegetation Index (DVI). A total of 72 sample plots of 0.1 ha were laid out in 11 plantation sites extended over an area of 647 ha in Timargara, Chakdara and Jandool. According to the results, all the selected plantation sites showed good performance in terms of survival rate, mostly above 90\%. In terms of species composition, Eucalyptus camaldulensis has the highest share (81\%) followed by Robinia pseduacacia with $17 \%$ and Pinus roxburghii with $2 \%$ share in the plantation. Growth performance was good in all species; Pinus roxburghii attained an average girth of $14.3 \mathrm{~cm}$ and height of 3.21 feet, whereas Eucalyptus camaldulensis and Robinia pseudoacacia attained a mean girth of 10.3 and $12.1 \mathrm{~cm}$ with the height of 8.6 and 8.2 feet in 27 months, respectively. Further, a good correlation was observed between the volume $\left(\mathrm{m}^{3}\right)$ and Landsat-8 spectral values. The highest performance $\left(R^{2}=0.63\right)$ was recorded by NDVI and SAVI. The temporal changes in spectral values of Landsat-8 images from 2013 to 2018 showed that the plantation was successful at these sites. The study concluded that FLR activities across the Khyber Pukhtunkwa province will rehabilitate and improve the existing forest ecosystems and support local livelihood for climate change mitigation.
\end{abstract}

Keywords: Billion Tree Afforestation Project, survival rate, growth performance, Landsat-8

\section{Introduction - Uvod}

Forest and landscape restoration (FLR) is an initiative to give new life to the unproductive, infertile and denuded land. It not only plays important role in strengthening the local communities and in restoration of biodiversity, but also plays a part in climate change mitigation (Maginnis et al. 2012). Forest and landscape projects are concerned with the activities related to regeneration of forests for the purpose to mitigate climate change. These projects have gained preference on the internation- al policy agenda (Jørgensen 2013). The restoration movement has recently gained strength and rapid momentum worldwide. Leaders are illustrating an exceptional political will for the achievement of tough and challenging goals internationally and nationally including the Aichi Targets, Bonn Challenge, and New York Declaration on Forests (Suding et al. 2015, Sabogal et al. 2015). Multilateral organizations, nongovernmental organizations and private sectors are making tremendous efforts for the achievement of restoration targets and goals extensively (IUCN 2014). Commitments by more than 20 
countries and regional initiative have been made for the conversion of infertile, unproductive, deforested and devalued land into highly productive, useable and biodiversity favorable terrains (Bonn Challenge 2015). Restoration plans, strategies, actions and policies have been made on national and sub-national level in many countries trying to find methods to merge and fuse the restoration strategies with the sustainable development and conservation agendas (Aguilar et al. 2015, Murcia et al. 2015, Chazdon et al. 2017).

In the context of FLR, Pakistan (Khyber Pukhtunkhwa) has implemented forest restoration and afforestation on 0.35 million hectares between 20152018. Billion Tree Afforestation Project (BTAP) is an initiative of mass afforestation and forest restoration to meet the Bonn Challenge commitment. BTAP is aimed at planning, designing, commencing and implementing »Green Growth Initiative« in the Forestry Sector of Khyber Pakhtunkhwa (KP) province. The project is being implemented by the KP Forest Department in the entire province through its three forest regions, namely Southern and Central region, Malakand region and Hazara region. Hazara region also includes the Watershed Management Circle. The project has been split into two phases: Phase I has been implemented during 2014-2015, while Phase II during 2015-2018. Major objectives of the project were to (i) launch sustainable development and restoration through active involvement of local communities, (ii) rehabilitate and improve existing forest ecosystems and (iii) enhance livelihood improvement and job creation for rural people including women (WWF-Pakistan, 2017). Massive plantation activities were conducted across the province inside forest areas, non-forest barren areas, canal side, river side, denuded hills and open spaces using participatory approach. Hundreds of nurseries were raised through forest department and local communities under BTAP. The present study was carried out in Dir Forest Division of KP province. BTAP carried out different intervention in Lower Dir, which include Block plantation on 4010 ha area, establishment of woodlots on 86 ha area and establishment of 345 private nurseries and eight departmental nurseries.

The present study was designed to assess survival rate of plantation, status of regeneration, species composition and growth performance of different species raised under BTAP. Further, the present study used vegetation indices derived from Landsat images to assess the temporal afforestation. Large geographic territories and their land cover can be easily and effectively estimated with the use of satellite data (Fonji and Taff 2014). Remote sensing has a benefit of collecting and examining time series images beneficially and cost effectively over large scale geographic terrains (Van Den Bergh et al. 2012, Neves et al. 2015). Different techniques can be used for afforestation mapping and monitoring. Previous studies discussed and reported various methods such as image differencing, image rationing, classification comparisons and image enhancement techniques (Jin et al. 2011, 2017, Matsushita et al. 2007, Zhu and Woodcock 2014). Different vegetation indices have been compared in prior studies based on vegetation monitoring and analysis (Ünsalan and Boyer 2004, Adan 2017, Ali et al. 2018, Imran and Ahmed 2018). Normalized Difference Vegetation Index (NDVI) mostly performed better than other indices and stands one of the most effective and successful indicators of vegetation density. NDVI has been used in various studies for global vegetation, crop assessment and vegetation growth (Hatfield and Prueger 2010, Zhumanova et al. 2018, Guan et al. 2019, Guo et al. 2020) and land cover (Jia et al. 2014, Ahmed and Akter 2017, Shimu et al. 2019, Eskandari et al. 2020). The present study used Landsat-8 images of 2013 and 2018 to assess temporal afforestation and map and monitor BTAP activities. Vegetation indices were computed from Landsat-8 images and used for temporal assessment of vegetation change. Landsat- 8 vegetation indices were also regressed against volume $\left(\mathrm{m}^{3}\right)$ and regression models were developed.

\section{Materials and methods-Materijal $i$ metode}

\subsection{Study area - Područje istraživanja}

The present study was conducted in the district of Malakand, which is located in the north-western part of Khyber Pakhtunkhwa province of Pakistan covering 158200 hectares (Fig. 1). This area falls in sub-tropical zone mostly and partly in moist temperate zone with altitudinal gradients. Malakand Forest Division comprises the following subdivisions: Timergara, Jandul and Chakdara. In terms of species composition, Abies pindrow and Picea smithiana occupy the highest elevations, Cedrus deodara and Pinus wallichiana the middle altitudes and Pinus roxburghii the lower areas. 

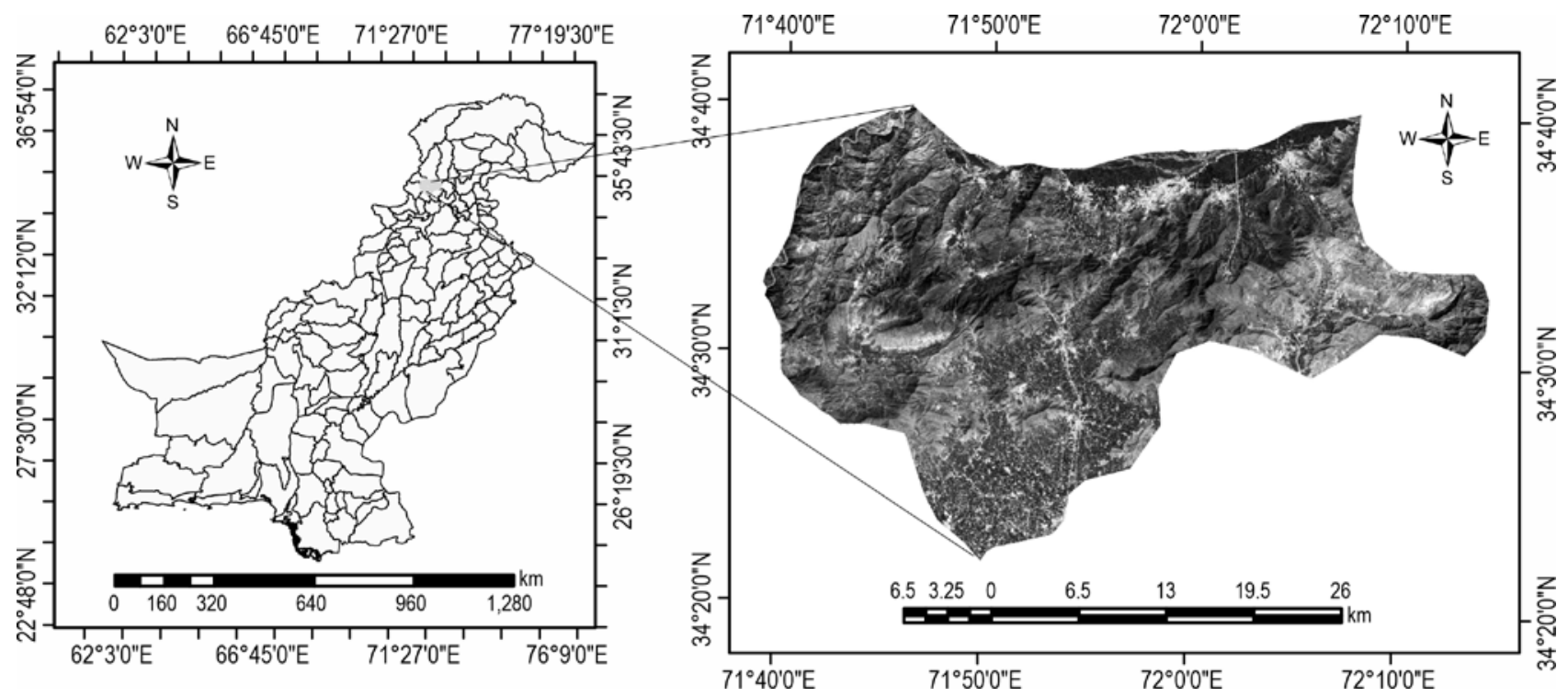

Fig. 1 Location of Malakand Forest Division in Pakistan (left) and study area presented using Landsat- 8 image (right) Slika 1. Položaj šumske regije Malakand u Pakistanu (lijevo) i područje istraživanja na slici s Landsat-8 (desno)

\subsection{Forest inventory - Inventarizacija šuma}

Forest inventory was conducted in plantation sites where BTAP activities were conducted from June to September 2018. Two stage random sampling was adopted for the selection of sample plot. First, ten sites were selected randomly from the list plantation provided by project management unit of billion tree afforestation project. In the second stage, five to twelve sample plots were selected in each site randomly. Thus, a total of 72 sample plots data were gathered to collect the information related to the BTAP activities in Jandool, Chakdara and Timergara forest subdivisions. Jandool subdivision plantation covered an area of 376 ha, Chakdara subdivision an area of $125 \mathrm{ha}$, while the total area of Timergara subdivision was 1213 ha. Data was collected from ten plantation sites through a circular sample plot having a radius of $18 \mathrm{~m}$, while considering slope correction. For the collection of data, a measuring tape is used along with a clinometer. First of all, a random point in the middle of the sample plot was considered, then the measuring tape was extended up to 18 meters by adjusting the slope through a clinometer. Regeneration was counted within the circle, and the girth and height of plants were measured in each sample plot and noted in the proforma design. All the collected data was transferred to the Microsoft excel sheet for the purpose of compilation and tabulation.

\subsection{Landsat-8 image acquisition and processing - Prikupljanje i obrada slika pomoću Landsat-8}

Landsat-8 images were downloaded for the sampled sites from USGS Explorer website (https:// earthexplorer.usgs.gov/). Landsat-8 was available in 2013 (before BTAP activities) and also for 2018 (after BTAP activities). Quality of images with minimum cloud cover were ensured and images were acquired for September 2018, which was the nearest time of in-situ field inventory (i.e June to September 2018). Pre-processing is crucial prior to vegetation extraction of satellite images for the purpose of removal of noise and escalation of interpretability of image data. Pre-processing comprises the processes of radiometric correction, geometric correction and ortho-rectification that have been managed and processed in ENVI 5.3 software for the images. Chlorophyll is used for the conversion of sun's radiant energy into organic energy. The absorptive properties of chlorophyll are distinctive as it absorbs wavelengths from red band of the electromagnetic spectrum, i.e. $645 \mathrm{~nm}$, and appears glassy to the wavelengths of near-infrared bands of the electromagnetic spectrum, i.e. $700 \mathrm{~nm}$. The distinctive absorptive characteristics of chlorophyll are being extensively used for designing the indices in the multispectral satellite imagery for the evaluation and estimation of 
local vegetation density. Vegetation indices, generally derived from the study of vegetative ratios, have been formed for the amplification of spectral difference based on highly strong vegetative absorbance and reflectance value in red band and near-infrared band of the electromagnetic spectrum, respectively. It is evident that the ratio of Near-Infrared (NIR) and Red (R) bands is highly associated with the quantity of green leaf biomass (Simard et al. 2016, Sowmya et al. 2017). For the purpose of volume mapping, different vegetation indices obtained from Landsat- 8 using SNAP tool were computed. Different indices, their formula and Landsat- 8 bands combination used in indices computation are listed in Table 1. There are different indices including (NDVI). The vegetation with active photosynthesis absorbs radiation, and the ratio of these two bands has been verified to be extremely correspondent with vegetation parameters such as green biomass (Gitelson et al. 2015). NDVI has the advantage of correcting the ultimate and terminal errors caused due to topography and shade. It also balances and neutralizes the fluorescence variation caused by the terrain as NDVI is the ratio of the two bands. Flourished and vigorous forests show high absorption value for red band (RED) and they also show high reflectance value for near infrared (NIR) portion of the electromagnetic spectrum. Contrary to this, bare ground, soil and rocks show almost equal values of reflectance for near-infrared and red bands of the electromagnetic spectrum, which estimates its NDVI value as nearly 0 . In case of water bodies, a reversed course is followed and the NDVI is negative. The distinction and differentiation between the vegetation cover and other land forms would be visibly magnified through NDVI image. Moreover, the temperate and tropical forests show high values of NDVI. The values of NDVI extend from 0.05 to 0.7 for sparse vegetation and dense vegetation, respectively (Fatiha et al. 2013). The description and classification of the ground and the extent to which it is covered or masked by vegetation can be determined by a variable of adjustment, which was found by Huete and is known as the Soil Adjusted Vegetation Index (SAVI), denoted by L. The parameter L gives the values for high and low density of the ground, which ranges from 0.25 to 1 . The value of $L$ for a medium density is equal to 0.5 . Conversions have been carried out of the forest attributes (volume data) into shape file (point data) through ArcGIS 10.3. The relative and correspondent vegetation indices of Landsat- 8 imagery were overspread by BTAP point data. The values of the pixels overlaid by inventory plots were evaluated for all vegetation indices.
Table 1 Vegetation indices computed from Landsat-8 product Tablica 1. Vegetacijski indeksi izračunati pomoću Landsat-8

\begin{tabular}{|c|c|c|c|}
\hline $\begin{array}{l}\text { Indices } \\
\text { Indeksi }\end{array}$ & $\begin{array}{l}\text { Formula } \\
\text { Formula }\end{array}$ & $\begin{array}{l}\text { Landsat-8 } \\
\text { Landsat-8 }\end{array}$ & $\begin{array}{c}\text { Original } \\
\text { Author } \\
\text { Izvor }\end{array}$ \\
\hline $\begin{array}{l}\text { Normalized Vegetation } \\
\text { Index (NDVI) } \\
\text { Normalizirani vegetaci- } \\
\text { jski indeks (NDVI) }\end{array}$ & $\begin{array}{l}(\text { NIR-Red }) \div \\
(\text { NIR + Red })\end{array}$ & $\begin{array}{c}(\mathrm{B} 5-\mathrm{B} 4) \div \\
(\mathrm{B} 5+\mathrm{B} 4)\end{array}$ & $\begin{array}{c}\text { Rouse et al., } \\
1973\end{array}$ \\
\hline $\begin{array}{c}\text { Soil Adjusted Vegetation } \\
\text { Index (SAVI) } \\
\text { Vegetacijski indeks } \\
\text { prilagođen tlu (SAVI) }\end{array}$ & $\begin{array}{c}((N I R-R) \div \\
(N I R+R+L)) \times \\
(1+L)\end{array}$ & $\begin{array}{c}((B 5-B 4) \div \\
(B 5 A+B 4+ \\
0.5)) \times(1+0.5)\end{array}$ & Qi et al., 1994 \\
\hline $\begin{array}{l}\text { Difference Vegetation } \\
\text { Index (DVI) } \\
\text { Razlikovni vegetacijski } \\
\text { indeks (DVI) }\end{array}$ & $N I R-R$ & (B5 - B4) & Jordan, 1969 \\
\hline $\begin{array}{l}\text { Modified Soil Adjust- } \\
\text { ed Vegetation Index } \\
\text { (MSAVI) } \\
\text { Modificirani indeks } \\
\text { vegetacije prilagođen tlu } \\
\text { (MSAVI) }\end{array}$ & $\begin{array}{l}1 \div 2[2 N I R+1- \\
\text { sqrt((2NIR+1)- } \\
8(N I R-R))\end{array}$ & $\begin{array}{c}1 \div 2[2 B 5+1- \\
\text { sqrt((2B5+1)- } \\
8(B 5-B 4))\end{array}$ & Qi et al., 1994 \\
\hline
\end{tabular}

\subsection{Statistical analysis - Statistička obrada podataka}

Scattered plots are used for the estimation and analysis of the data between the volume and individual indices. Correlation and regression analysis was developed between biomass and spectral indices. Each model was assessed for the calculation of coefficient of determination $\left(R^{2}\right)$. The best suitability of a model was assessed on the basis of the value of $R^{2}$. The model with the highest value and condition of $R^{2}$ was considered to be the best.

\section{Results and discussion - Rezultati i rasprava}

\subsection{Survival rate of plantation - Stopa preživljavanja plantaže}

Results showed that the overall survival rate in plantation areas was $94.17 \%$ (Table 2). It was found that the highest survival rate has been achieved in Timergara followed by Jandool and Chakdara with $94.86 \%, 94.01 \%$, and $93.64 \%$ survival rates, respectively. The comparatively high rate of survival is probably due to choice of species, i.e. most of the plantations consist of Eucalyptus which shows a very high survival rate in harsh conditions, and secondly due to intensive care provided by the department. The high survival rate is due to additional sowing in pits and proper maintenance. Sowing in pits has supplemented the failed plants significantly. 
The data further revealed that there is no significant variation in survival percentage of all selected sites, which means that the sowing has been carried out in all plantation sites. The data regarding survival rate in the selected sites is given in Table 2. Further, species wise survival rate was also recorded during the study. It was found that there is no significant difference among various species in terms of survival rate. Eucalyptus was planted for the purpose of afforestation and on problematic sites because of its rapid and fast growth accompanied by its adaptability with existing environmental conditions (Zahid et al. 2010). In the early $20^{\text {th }}$ century, eucalyptus species were launched in Pakistan and were planted on millions of hectares of land in the country (Zahid et al. 2016).

Table 2 Site wise survival rate Tablica 2. Stopa preživljavanja

\begin{tabular}{|c|c|c|c|c|}
\hline $\begin{array}{c}\text { S.No } \\
R . \text { broj }\end{array}$ & $\begin{array}{c}\text { Site } \\
\text { Ploha }\end{array}$ & $\begin{array}{c}\text { Total pits } \\
\text { Ukupno } \\
\text { jame }\end{array}$ & $\begin{array}{c}\text { Empty pits } \\
\text { Prazne jame }\end{array}$ & $\begin{array}{c}\text { Survival } \\
\text { Preživljavanje }\end{array}$ \\
\hline 1 & Junikally & 810 & 34 & 94.56 \\
\hline 2 & Takwaro & 505 & 21 & 93.68 \\
\hline 3 & Chilgaza & 465 & 27 & 94.34 \\
\hline 4 & Gumbatkaye & 816 & 24 & 95.05 \\
\hline 5 & NagariaBala & 1386 & 56 & 94.12 \\
\hline 6 & Saferae & 543 & 16 & 97.05 \\
\hline 7 & Shalkanai & 1107 & 47 & 94.15 \\
\hline 8 & Hashim munda & 588 & 26 & 95.51 \\
\hline 9 & Asman banda & 990 & 27 & 94.67 \\
\hline 10 & Laram Road & 289 & 13 & 95.11 \\
\hline 11 & Malakand university & 273 & 17 & 94.89 \\
\hline & Total - Ukupno & 7773 & 308 & 94.17 \\
\hline
\end{tabular}

\subsection{Species composition in plantation - Vrste u plantaži}

To know the species composition in the plantation area, species wise numbers of plants were recorded in each sample plot. It was found that three different species have been planted under BTAP in the selected sites. Out of these species, Eucalyptus has the highest share, i.e. $81 \%$ followed by Robinia with $17 \%$, whereas the share of Chirpine is only $2 \%$ in the total plantations. Eucalyptus and Robinia are the major species in these plantations. This is part- ly because Eucalyptus has more chances of survival in dry conditions. Robinia is also a very promising species in dry area but its growth is affected by frost, which is the reason of low percentage of Robinia in the plantations. According to WWF (2017), overall survival rate of Eucalyptus plants in hilly and waterlogged areas found in lower Dir is $91.62 \%$. The KPKP forest department carried out the analysis of 70,448 ha plantations in 2016. WWF Pakistan monitored 15,888.73 ha at 177 sites with 40 sites in southern region (WWF, 2016). KP forest department has planted more than 27 species in the entire province. Major species are Eucalyptus, Chir pine, Robinia, Acacia modesta, Acacia nilotica, Shisham, etc. Further, it was observed that plantation of Eucalyptus increased from 17\% to $48 \%$ from 2016 to 2017. The reason behind this was mainly farmer's preference because of its suitability and fast growth (high volume) in less time.

\subsection{Growth rate of different species - Stopa rasta različitih vrsta}

The growth rates of different species (girth, height and age) are summarized in Table 3. Highest growth performance was exhibited by Eucalyptus. Eucalyptus attained an average girth of $10.7 \mathrm{~cm}$ and height of $2.01 \mathrm{~m}$ in just one year and a half. This high growth was due to very good conditions of the sites where eucalyptus were planted. On the other hand, Robinia attained an average girth of $9.92 \mathrm{~cm}$ and height of $2.11 \mathrm{~m}$ in two years. Data on growth performance of different tree species at different ages were also recorded to determine variation in growth at different time intervals (Table 3). Temporal growth of Eucalyptus was also recorded and showed that this species achieved a girth of $9.55 \mathrm{~cm}$ and height of $1.82 \mathrm{~m}$ in 18 months. Further, older plantation of Eucalyptus achieved a girth of $11.85 \mathrm{~cm}$ and height of $3.25 \mathrm{~m}$ in 26 months, which is significantly higher than Robinia and other species. Significant research has been done to characterize (Mahmood et al. 2009) and assess the distinguishing characteristics influencing the biomass production and productivity of eucalyptus in the environments vulnerable to drought (Zahid and Nawaz 2007). Eucalyptus is highly water demanding, which may cause deficiency and reduction of aquifer reservoirs for irrigated plantations in arid and semi-arid conditions (Zahid et al. 2010). 
Table 3 Recorded data of various age classes of different species Tablica 3. Zabilježeni podaci različitih dobnih razreda različitih vrsta

\begin{tabular}{|c|c|c|c|c|c|}
\hline $\begin{array}{c}\text { S.No } \\
\text { R. broj }\end{array}$ & $\begin{array}{c}\text { Species } \\
\text { Vrsta }\end{array}$ & $\begin{array}{c}\text { Site } \\
\text { Ploha }\end{array}$ & $\begin{array}{c}\text { Age } \\
\text { (months) } \\
\text { Godine } \\
\text { (mjeseci) }\end{array}$ & $\begin{array}{c}\text { Girth at } \\
\text { base } \\
\text { Prsni } \\
\text { promjer }\end{array}$ & $\begin{array}{c}\text { Height } \\
\text { Visina }\end{array}$ \\
\hline 1 & Eucalyptus & JuniKally & 18 & 9.55 & 1.82 \\
\hline 2 & Eucalyptus & Asman Banda & 26 & 11.85 & 3.25 \\
\hline 3 & Eucalyptus & HashimMunda & 28 & 12.05 & 3.43 \\
\hline 4 & Robinia & JuniKally & 18 & 10.71 & 1.97 \\
\hline 5 & Robinia & Asman Banda & 26 & 10.6 & 2.65 \\
\hline 6 & Robinia & Gumbatkaye & 20 & 9.87 & 2.2 \\
\hline 7 & Chirpine & Malakand University & 30 & 14.36 & 0.92 \\
\hline
\end{tabular}

\subsection{Spectral indices and volume $\left(\mathrm{m}^{3}\right)$ -} Spektralni indeksi i obujam $\left(\mathrm{m}^{3}\right)$

Landsat-8 derived spectral indices are shown in Fig. 2. It is clearly shown by all indices that forest
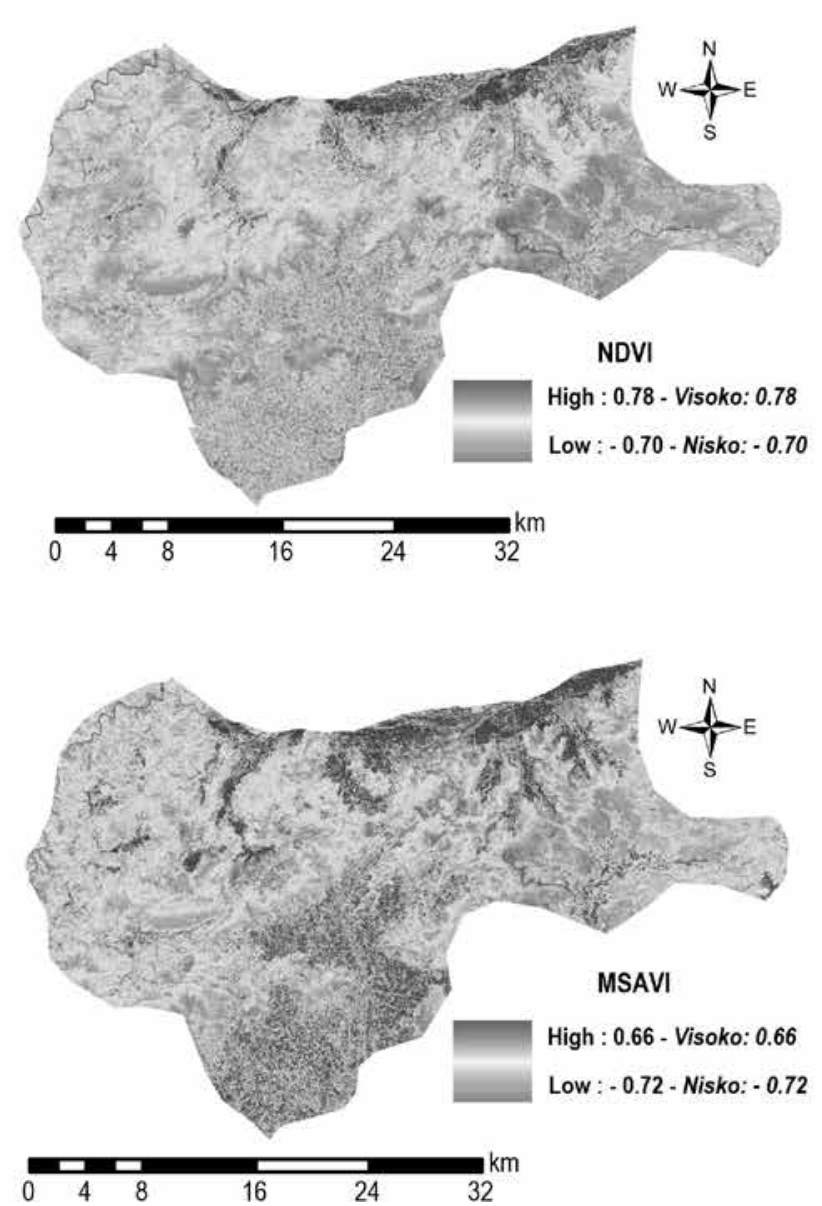

areas are present in northern part of the study area, while southern parts are mostly composed of agricultural land. Bare rocks and mountainous terrain are present in eastern and western parts. All indices indicated forest areas, however agricultural crops were somewhat exaggerated in MSAVI. Further, NDVI and SAVI have mapped forest vegetation accurately compared to MSAVI and DVI because the former has overestimated and later underestimated forest areas. Fig. 3 (A) shows the scatterplot between volume $\left(\mathrm{m}^{3}\right)$ values from field data and NDVI values derived from Landsat- 8 image. The coefficient of correlation was 0.63 , which means that $63 \%$ of field data have been explained by the NDVI-based model, while $37 \%$ of the data have not been explained by this model. However, Landsat- NDVI is a proxy data and above $30 \%$ correlation is considered good. The correlation of NDVI was the same as SAVI and greater than MSAVI and DVI. Similarly, SAVI has the same coefficient of correlation (0.63) as depicted in the scatterplot Fig 3 (B). The correlation of SAVI
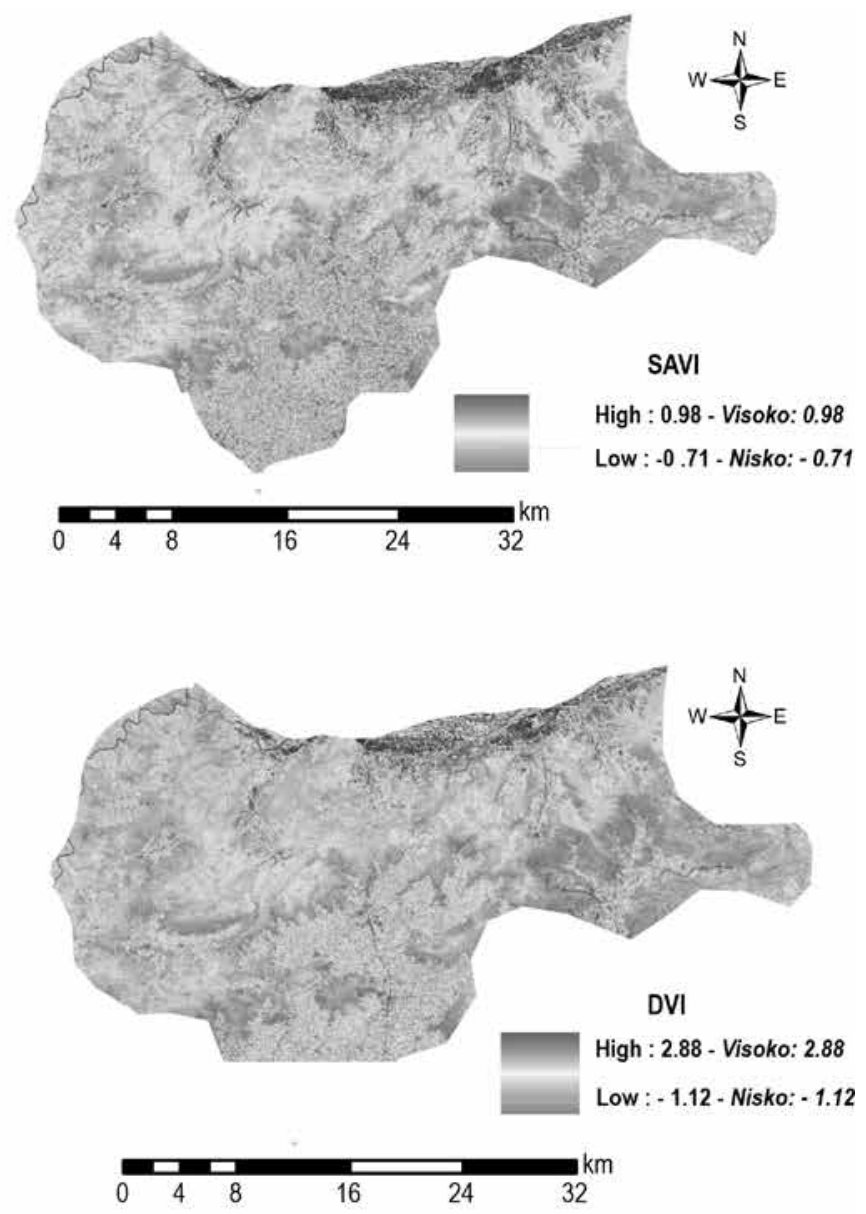

Fig. 2 Landsat-8 spectral indices

Slika 2. Spektralni indeksi Landsat-8 
and NDVI with volume was highest $\left(\mathrm{R}^{2}=0.63\right)$ as compared to other indices (MSAVI and DVI). The Modified Soil Adjusted Vegetation Index (MSAVI) also performed well and has shown $\mathrm{R}^{2}$ of 0.58 , while Difference Vegetation Index (DVI) has shown a correlation of $59 \%\left(R^{2}=0.59\right)$ in Fig. 3(D). The MSAVI has performed lower than the rest of the indices (NDVI, SAVI and DVI) in Fig. 3(C). Wilson and Sader (2002) found, using multi-date Landsat images to identify
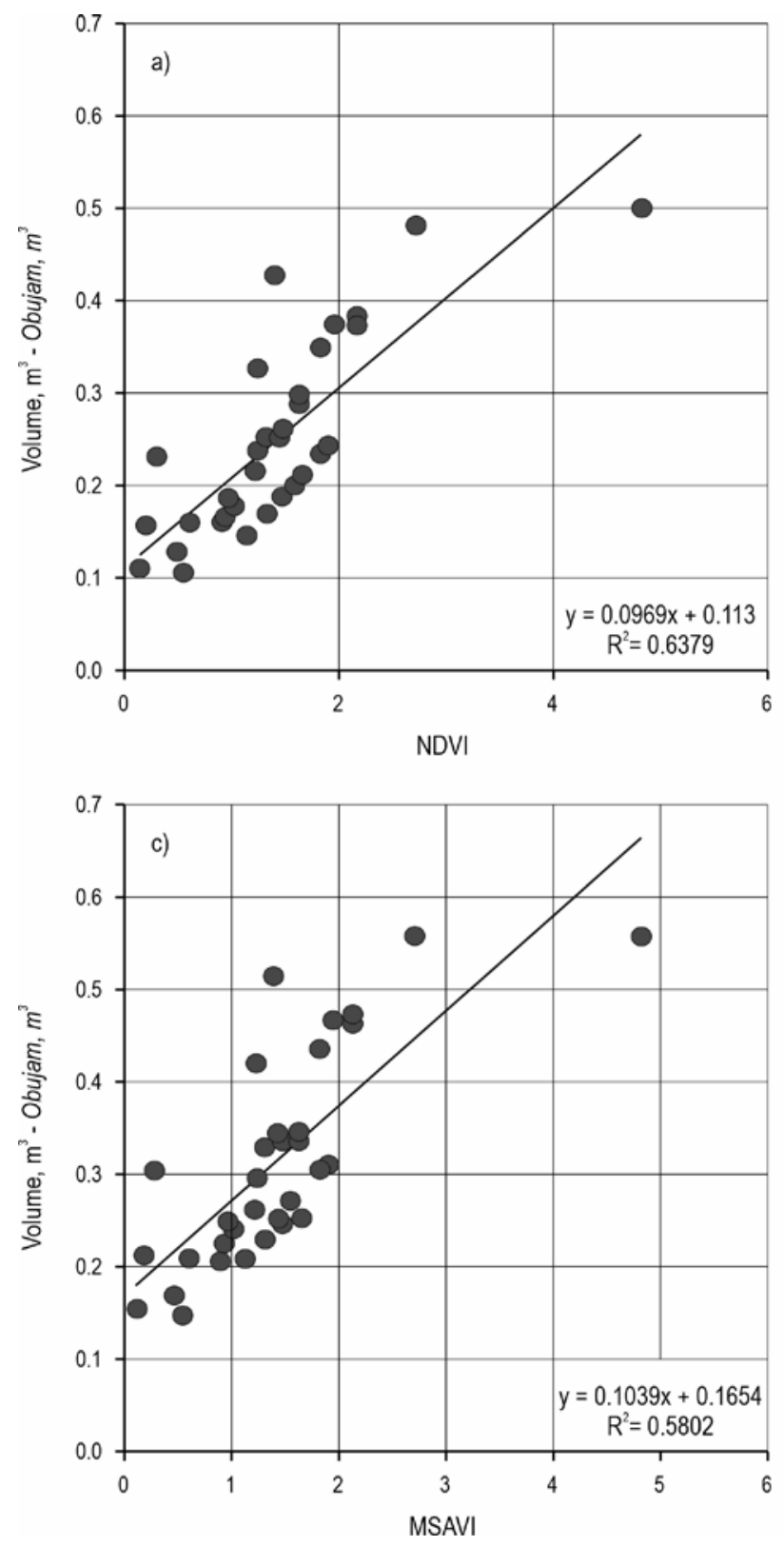

forest change accurately, that land change patterns can be detected with high accuracy through vegetation indices. Pickell et al. (2016) reported that monitoring of forest recovery can be assesed through tasseled cap index, NDVI, and Normalized Burned Ratio. Trajectories of all tasseled cap indices can be used to understand the forest recovery process and contains more detail on vegetation structure and growth (Frazier et al. 2015).
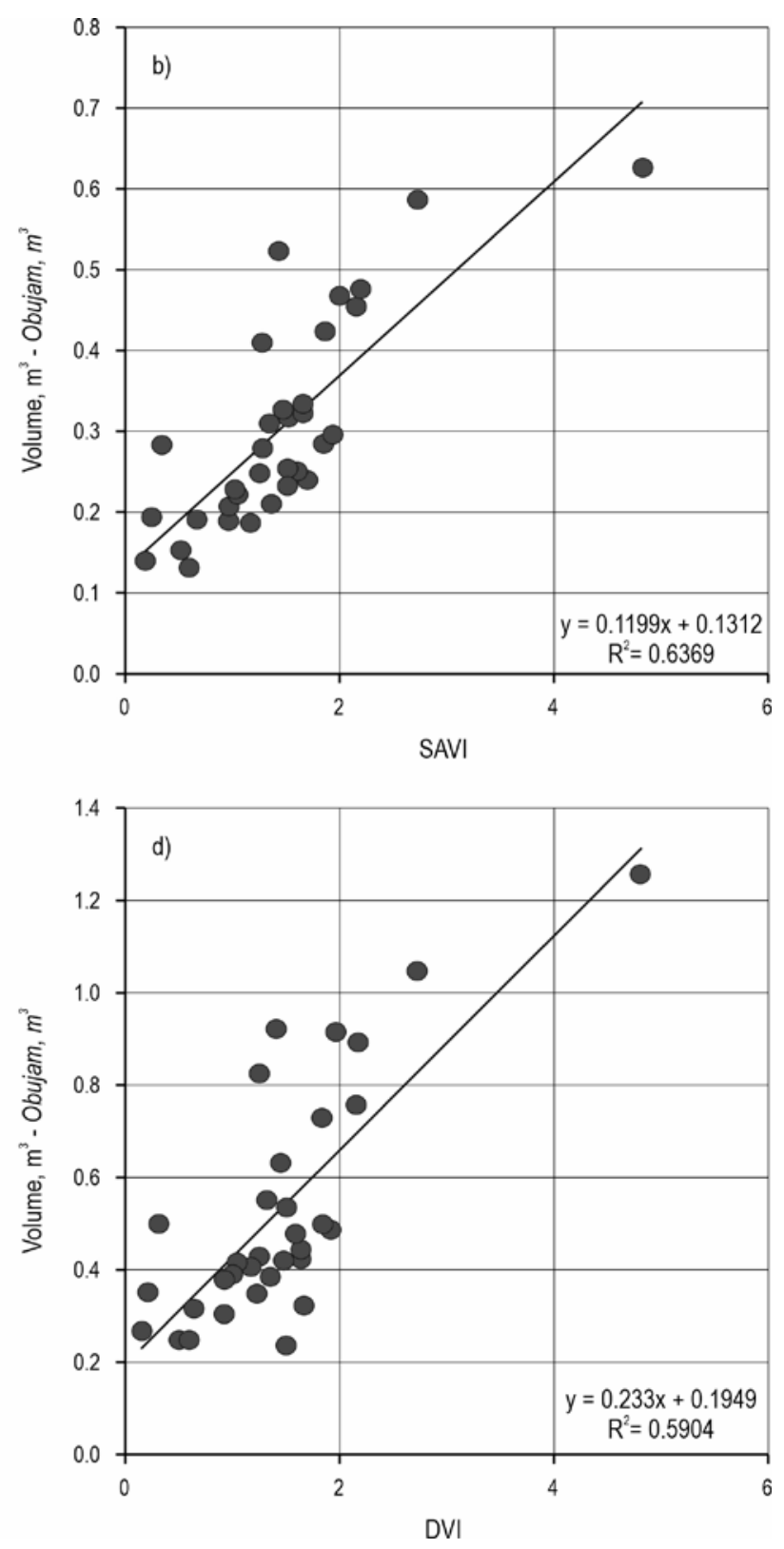

Fig. 3 Scatterplots between Landsat-8 spectral indices and volume $\left(\mathrm{m}^{3}\right)$

Slika 3. Dijagrami raspršenja između spektralnih indeksa Landsat-8 i obujma $\left(\mathrm{m}^{3}\right)$ 
3.5 Spectral indices and survival percentage Spektralni indeksi i postotak preživljavanja

Survival percentage at each site was also correlated with spectral indices and the resultant scatterplots are presented in Fig. 4. All scatterplots show good, positive and linear relationships between spectral indices and survival percentage. There were only a few outliers in data that contained the
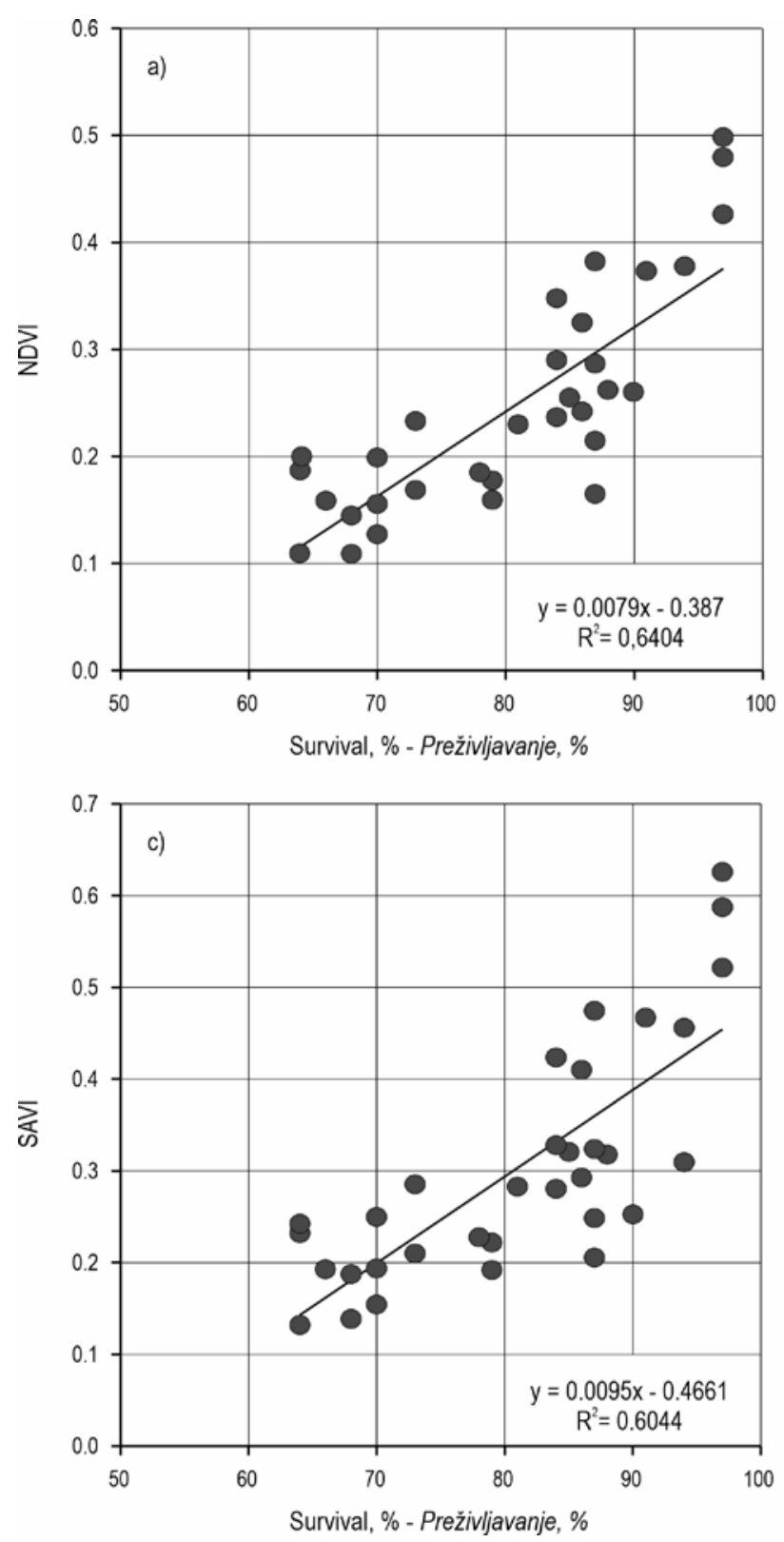

highest survival percentages (98-99\%). Among four computed indices, NDVI has shown the highest coefficient of correlation $\left(R^{2}=0.64\right)$ and the regression model has explained $64 \%$ of survival data, while the remaining data $(36 \%)$ remained unexplained. Similarly, the performance of MSAVI was better $\left(R^{2}=0.61\right)$, followed by SAVI with the coefficient of correlation $\left(R^{2}=0.60\right)$, whereas DVI showed the lowest correlation $\left(R^{2}=0.46\right)$.
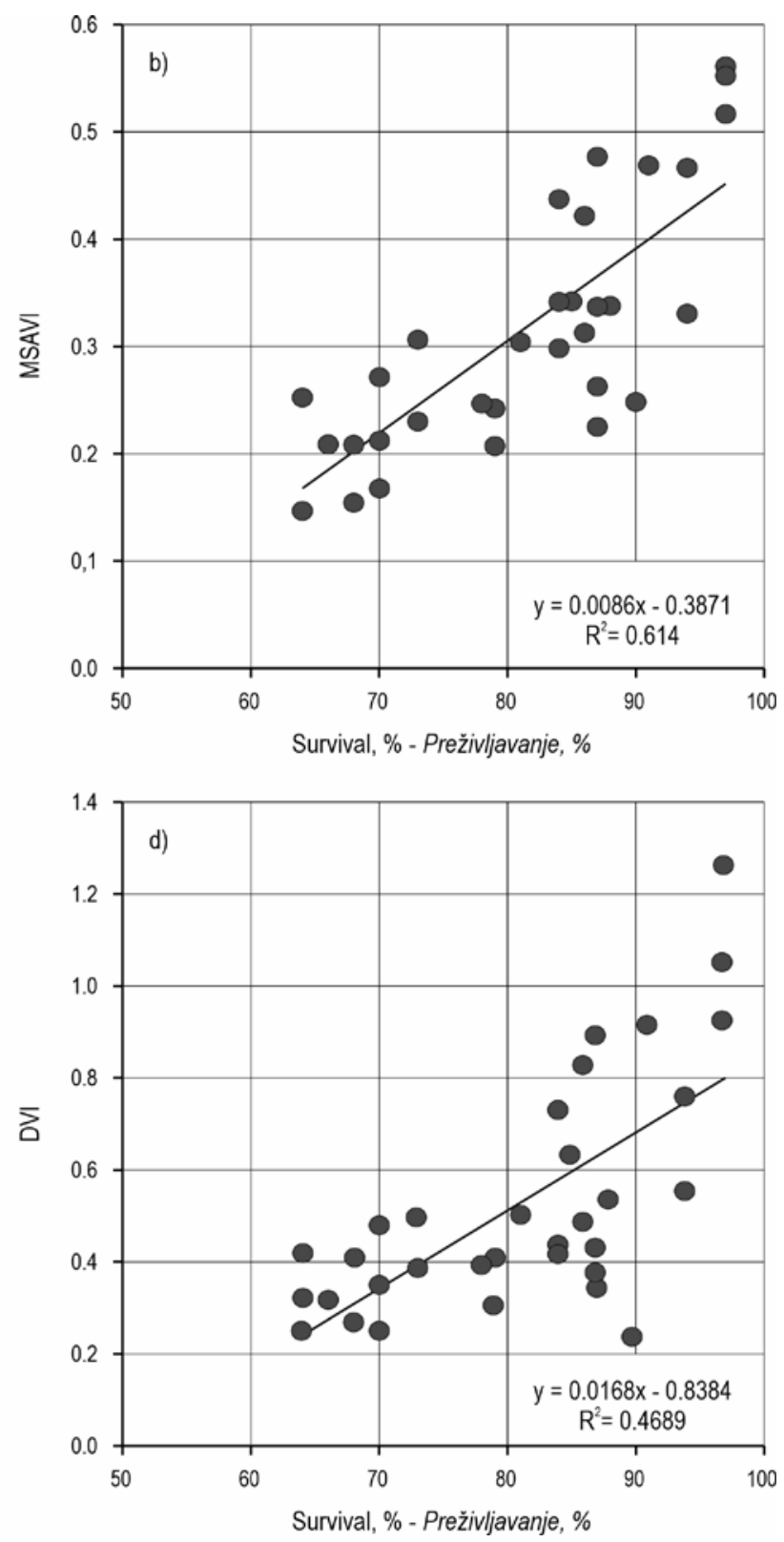

Fig. 4 Spectral indices and survival percentage

Slika 4. Spektralni indeksi i postotak preživljavanja 


\subsection{Temporal change afforestation sites - Vremenska promjena mjesta pošumljavanja}

The temporal changes in NDVI values of 30 plantation sites are shown in Fig. 5. NDVI values are very low in 2013, which shows that before afforestation activities there was no vegetation. Most NDVI values range from -0.1 to 0.1 in 2013 , which indicates no vegetation at these sites. The maximum value was 0.1 , while the lowest was 0.2 at plantation sites 29 and 21, respectively. After the afforestation activities, in 2018 the NDVI values increased at most

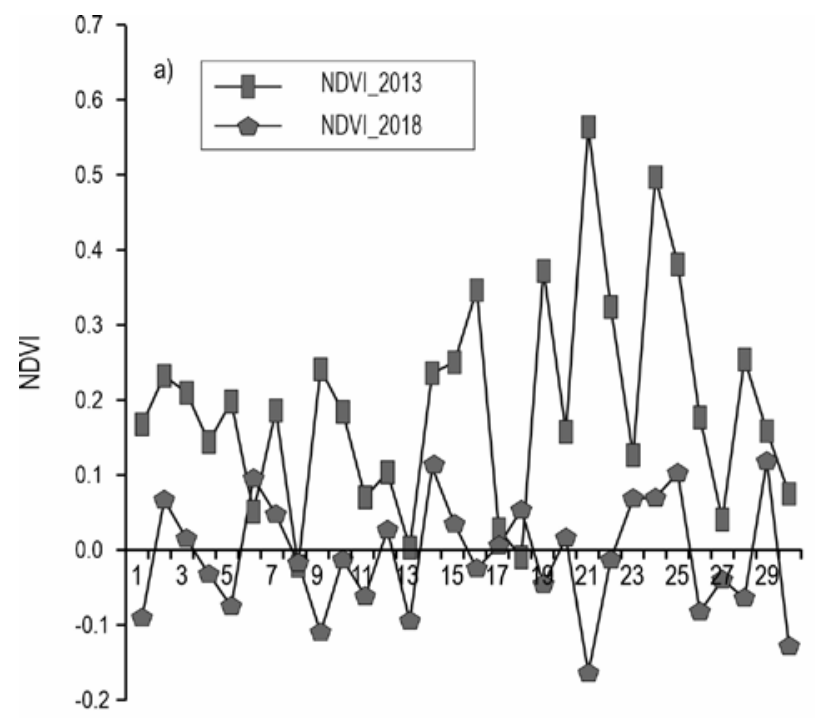

Plantation points - Mjesta na plantaži

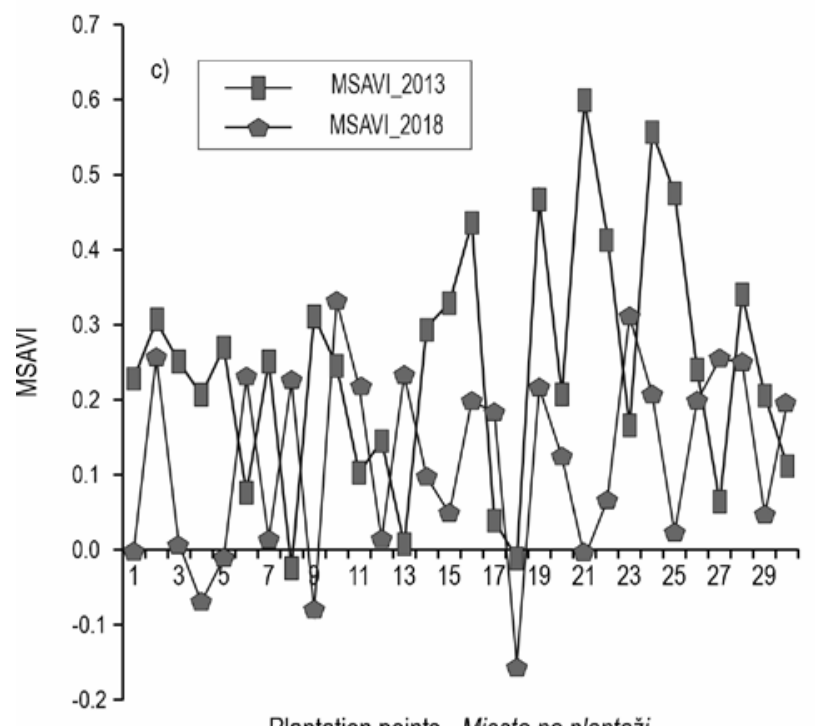

Fig. 5 Temporal changes in NDVI values

Slika 5. Vremenske promjene vrijednosti NDVI of the plantation sites except a few (Fig. 6). The reason of plantation failure may be due to climatic or management factors. NDVI values have been computed from Landsat- 8 image, which is why medium spatial resolution (30 meters) might not be able to detect small area temporal changes at these sites. However, the temporal positive change in NDVI values showed that afforestation was successful at most of the sites. After afforestation activities, most of the NDVI values ranged from 0.1 to 0.5 , while the highest temporal changes were recorded in plantation sites 19 to 26 .

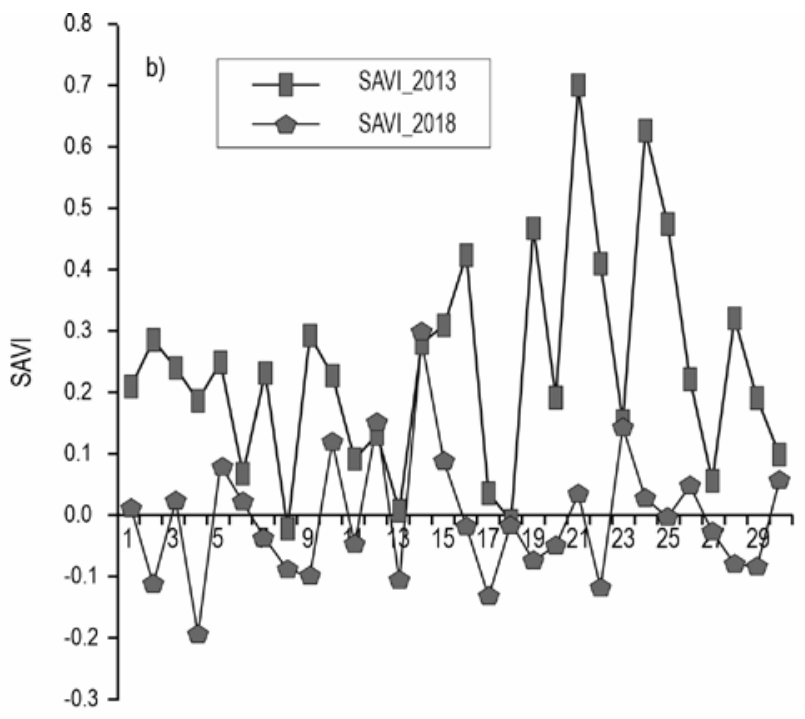

BTAP Plantation points - BTAP mjesta na plantaži

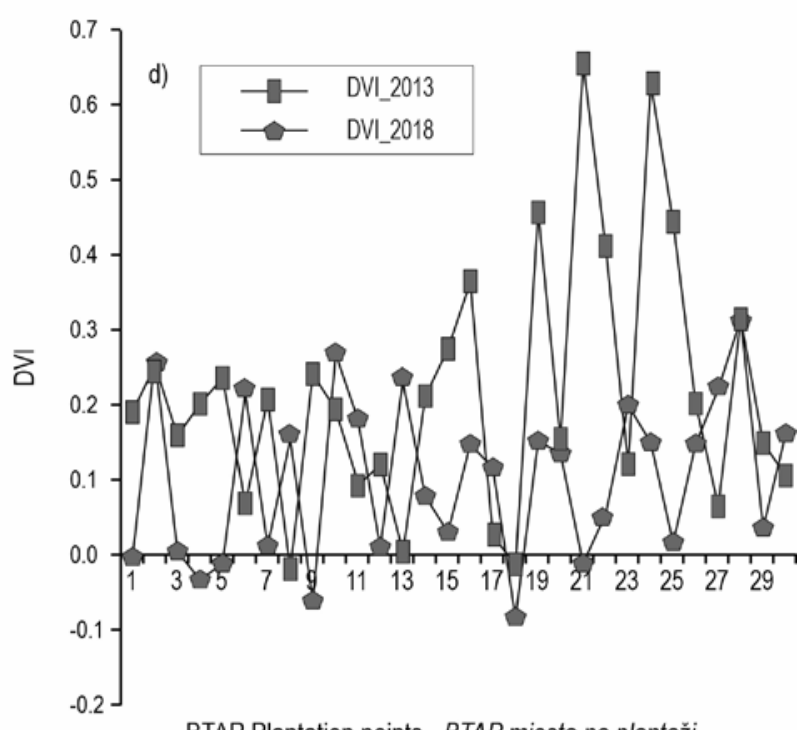

BTAP Plantation points - BTAP mjesta na plantaži 
Similarly, the temporal changes in all other indices (SAVI, MSAVI and DVI) also showed the same positive changes from 2013 (before plantation) and 2018 (after plantation). Temporal analysis is carried out using Landsat image data and historical record, making it easier to include satellite data into monitoring processes (Nagendra et al. 2013). Guo et al. (2018) assessed the potential of eighteen spectral indices derived from time-series Landsat data to characterize the different stages of afforestation. Afforestation was identified through land use tra-
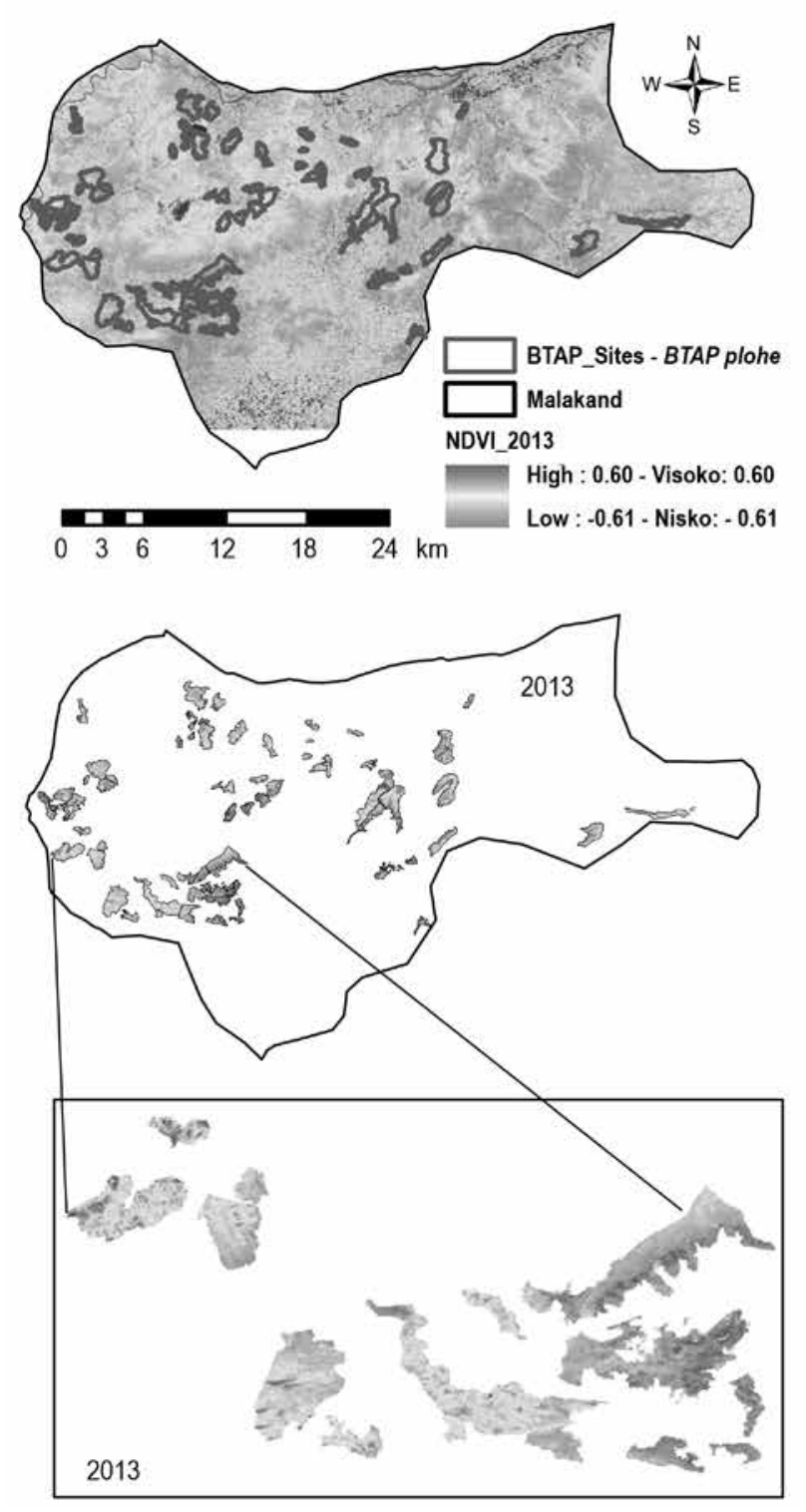

Fig. 6 Temporal afforestation (before and after BTAP)

Slika 6. Vremensko pošumljavanje (prije i poslije BTAP-a) jectories analysis and NDVI differencing (Wang et al. 2018). The impact of restoration activities was analyzed by comparing TM digital data of 1986 (before restoration) and LISS III digital data of 2002 (after restoration), and it reported a $90 \%$ increase in the mangrove forest cover (Selvam et al. 2003). Ayanlade et al. (2017) further stated that, in a region where vegetation cover is low, NDVI differencing is not effective because of the predominance of background effects. NDVI is also affected by atmospheric conditions according to Van Leeuwen et al. (2006) and
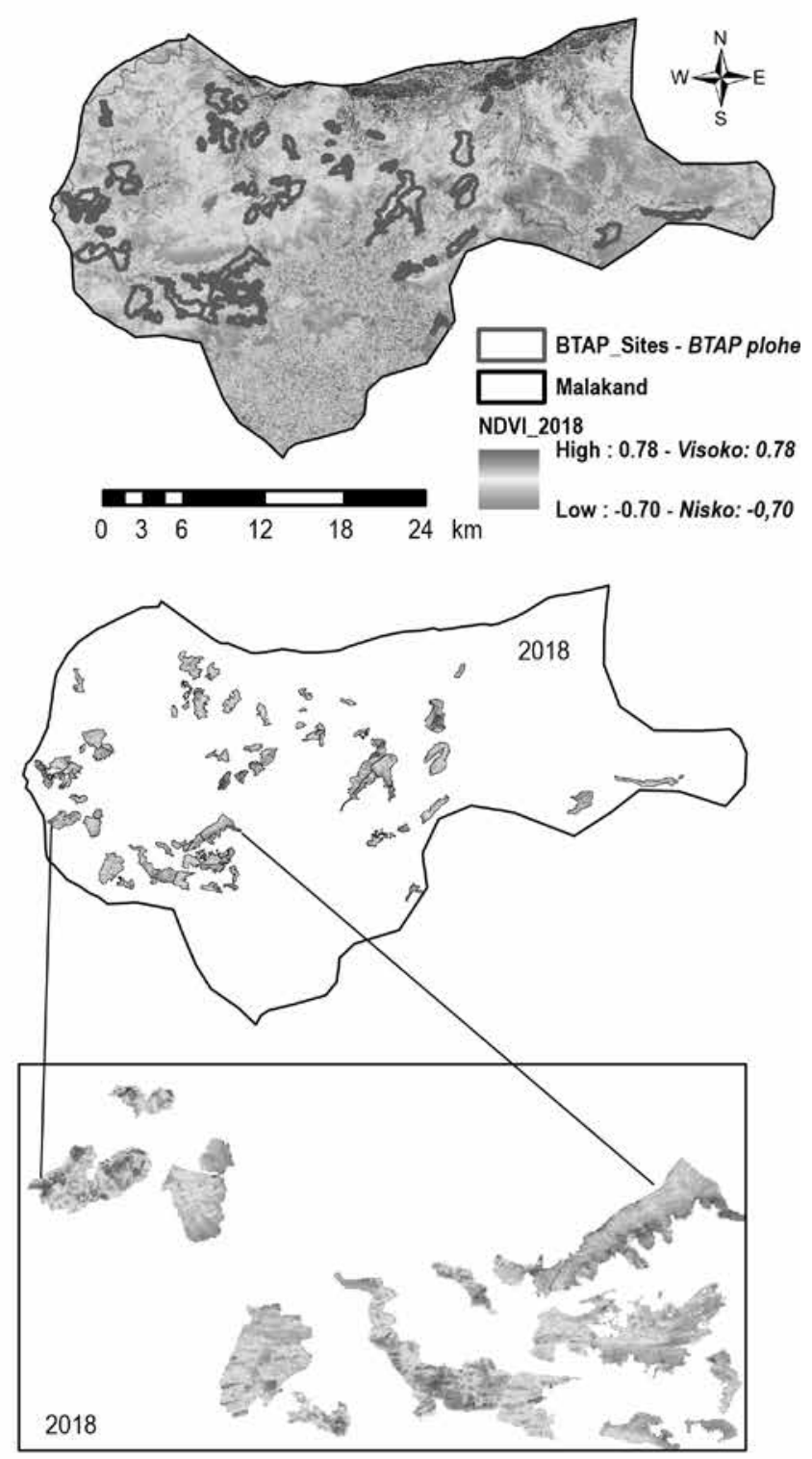
Ji and Peters (2007), who noticed slight changes in NDVI differencing values between two dates as a result of differences in atmospheric conditions, with increased haze leading to a reduction in NDVI.

\section{Conclusions - Zaključci}

In the present study, 72 afforestation sample sites (pixels) were randomly chosen and visually interpreted using high resolution historical Google Earth images and Landsat time series data to determine the year of plantation, so that the results can be analyzed and proved. Remote sensing is an interesting technology as it provides a vast range of data and tools while estimating vegetation dynamics. Strong relationship can be established between vegetation cover and recovered forest structure. Landsat time series analysis is crucial when detecting the change of vegetative state. To examine vegetation and land use changes, Landsat- 8 NDVI should be used for mapping temporal changes in vegetation. Afforestation samples along with the year of plantation helped to estimate exactly how many years it took for saplings to grow. Spectral indices would be helpful in estimating the success of FLR through forest inventory and Landsat-8, but important challenges still need to be tackled to ensure a realistic monitoring of FLR progress at such a wide scale on all the aspects of monitoring: environmental, socioeconomic and enabling environments.

\section{Acknowledgement - Zahvala}

This study is an outcome of contribution of BS Forestry graduates of PMAS Arid Agriculture University, Rawalpindi and Pakistan Forest Institute, Peshawar, Pakistan.

\section{References - Literatura}

Ahmed, K. R., Akter, S., 2017: Analysis of landcover change in southwest Bengal delta due to floods by NDVI, NDWI and K-means cluster with Landsat multi-spectral surface reflectance satellite data. Remote Sensing Applications: Society and Environment 8: 168-181. https://doi. org/10.1016/j.rsase.2017.08.010

Adan, M. S., 2017: Integrating Sentinel-2A derived indices and terrestrial laser scanner to estimate above ground biomass/carbon in Ayer Hitam tropical forest, Malaysia. Master of Science, University of Twente, The Netherlands. https://webapps.itc.utwente.nl/librarywww/papers_2017/msc/nrm/adan.pdf

Aguilar, M., Sierra, J., Ramirez, W., 2015: Toward a post-conflict Colombia: restoring to the future. Restor Ecol. 23: 4-6.
Ali, A., Ullah, S., Bushra, S., Ahmad, N., Ali, A., Khan, M. A., 2018: Quantifying forest carbon stocks by integrating satellite images and forest inventory data. Aust. J. For. Sci. 135(2): 93-117.

Ayanlade, A., 2017: Remote sensing vegetation dynamics analytical methods: a review of vegetation indices techniques. Geoinfor Polon. 2017: 7-17.

Bonn Challenge, 2019: Available at http://www.bonnchallenge.org/. Accessed December 6, 2019.

Chazdon, R. L., Brancalion, P. H., Lamb, D., Laestadius, L., Calmon, M., Kumar, C., 2017: A policy-driven knowledge agenda for global forest and landscape restoration. Conserv Lett. 10(1): 125-132. https://doi.org/10.1111/ conl.12220.

Eskandari, S., Reza Jaafari, M., Oliva, P., Ghorbanzadeh, O., Blaschke, T., 2020: Mapping land cover and tree canopy cover in Zagros forests of Iran: Application of Sentinel-2, Google Earth, and field data. Remote Sensing, 12(12), 1912. https://doi.org/10.3390/rs12121912.

Fatiha, B., Abdelkader, A., Latifa, H., Mohamed, E., 2013: Spatio temporal analysis of vegetation by vegetation indices from multi-dates satellite images: Application to a semi arid area in ALGERIA. EnergyProcedia 36: 671-687. https://doi.org/10.1016/j.egypro.2013.07.077

Fonji, F. S., Taff, N. G., 2014: Using satellite data to monitor land-use land-cover change in North-eastern Latvia. SpringerPlus 3(1): 61-72.

Frazier, R. J., Coops, N. C., Wulder, M. A., 2015: Boreal shield forest disturbance and recovery trends using landsat time series. Remote Sens. Environ. 170: 317-327. https://doi.org/10.1016/j.rse.2015.09.015

Gitelson, A. A., Peng, Y., Arkebauer, T. J., Suyker, A. E., 2015: Productivity, absorbed photosynthetically active radiation, and light use efficiency in crops: Implications for remote sensing of crop primary production. J. Plant Physiol. 177: 100-109. https://doi.org/10.1016/j. jplph.2014.12.015

Go, K. P., 2015: Revised PC-1 for Billion Trees Tsunami Afforestation Project in Khyber Pakhtunkhwa, Department of Forestry, Environment \& Wildlife Govt. of Khyber Pakhtunkhwa, Pakistan. https://doi.org/10.3390/f.10080703

Guan, Q., Yang, L., Guan, W., Wang, F., Liu, Z., Xu, C., 2019: Assessing vegetation response to climatic variations and human activities: spatiotemporal NDVI variations in the Hexi Corridor and surrounding areas from 2000 to 2010. Theoretical and Applied Climatology 135(3): 1179-1193. https://doi.org/10.1007/s00704-018-2437-1

Guo, J., Gong, P., 2018: The Potential of Spectral Indices in Detecting Various Stages of Afforestation over the Loess Plateau Region of China. Remote Sens. 10(9): 1492-1507. https://doi.org/10.3390/rs10091492

Guo, Y., Zeng, J., Wu, W., Hu, S., Liu, G., Wu, L., Bryant, C. R., 2021: Spatial and Temporal Changes in Vegetation in 
the Ruoergai Region, China. Forests 12(1): 76. https://doi. org/10.3390/f12010076.

Hatfield, J.R., Prueger, J. H., 2010: Value of using different vegetative indices to quantify agricultural crop characteristics at different growth stages under varying management practices. Remote Sens. 2: 562-578. https://doi. org/10.3390/rs2020562

Imran, A. B., Ahmed, S., 2018: Potential of Landsat- 8 spectral indices to estimate forest biomass. Int. J. Hum. Cap. Urban Manag. 3(4): 303-314.

IUCN, W., 2014: A guide to the Restoration Opportunities Assessment Methodology (ROAM): Assessing forest landscape restoration opportunities at the national or sub-national level. Working Paper (Road-test edition). Gland, Switzerland: IUCN, p. 125. Available at https:// www.iucn.org/downloads/roam_handbook_lowres_ web.pdf

Ji, L., Peters, A. J., 2007: Performance evaluation of spectral vegetation indices using a statistical sensitivity function. Remote Sens. Environ. 106(1): 59-65.

Jia, K., Liang, S., Wei, X., Yao, Y., Su, Y., Jiang, B., Wang, X., 2014: Land Cover Classification of Landsat Data with Phenological Features Extracted from Time Series MODIS NDVI Data. Remote Sens. 6: 11518-11532. https://doi. org/10.3390/rs61111518

Jin, S., Yang, L., Danielson, P., Homer, C., Fry, J., Xian, G., 2011: A comprehensive change detection method for updating the National Land Cover Database to circa. Remote Sens. Environ. 132: 159-175. https://doi.org/10.1016/j. rse.2013.01.012

Jin, S., Yang, L., Zhu, Z., Homer, C., 2017: A land cover change detection and classificationprotocol for updating Alaska NLCD 2001 to 2011. Remote Sens. Environ. 195: 44-55. https://doi.org/10.1016/j.rse.2017.04.021.

Jordan, C. F., 1969: Derivation of leaf-area index from quality of light on the forest floor. Ecology 50(4): 663-666.

Jørgensen, D., 2013: Ecological restoration in the Convention on Biological Diversity targets. Biodivers Conserv. 22: 2977-2982.

Khan, M. A. A., 2015: Green Growth Initiative of Khyber Pakhtunkhwa Province, Pakistan. Int. J. Green Growth Dev. 1(2): 125-132.

Maginnis, S., Rietbergen-McCracken, J., Sarre, A., 2012: The forest landscape restoration handbook. (Eds.) Routledge.

Mahmood, K. H., Naqvi, N. E., Marcar, N. E., 2009: Genetic variation in Eucalyptus camaldulensis Dehnh., in a provenance-family trial on saline soil. Pak. J. Bot. 41(5): 2281-2287.

Matsushita, B., Yang, W., Chen, J., Onda, Y., Qiu, G., 2007: Sensitivity of the enhanced vegetation index (EVI) and normalized difference vegetation index (NDVI) to topo- graphiceffects: a case study in high-density cypress forest. Sensors. 7(11): 2636-2651. https://doi.org/10.3390/ s7112636.

Murcia, C., Guariguata, M. R., Andrade, Á. Andrade, GI., Aronson, J., Escobar, E. M., Etter, A., Moreno, F. H., Ramírez, W., Montes, E., 2015: Challenges and prospects for scaling-up ecological restoration to meet international commitments: Colombia as a case study. Conserv Lett. 9(3): 213-220. https://doi.org/10.1111/conl.12199.

Nagendra, H., Lucas, R., Honrado, J. P., Jongman, R. H. G., Tarantino, C., Adamo, M., Mairota, P., 2013: Remote sensing for conservation monitoring: assessing protected areas, habitat extent, habitat condition, species diversity, and threats. Ecol Indic. 33: 45-59. https://doi.org/10.1016/j. ecolind.2012.09.014

Neves, A. K., Bendini, H. N., Körting, T. S., Fonseca, L. M. G., 2015: Combining time series features and data mining to detect land cover patterns: a case study in northern matogrosso state, brazil. InGeoInfo, 174-185.

Pickell, P. D., Hermosilla, T., Frazier, R. J., Coops, N. C., Wulder, M. A., 2016: Forest recovery trends derived from landsat time series for north american boreal forests. Int. J. Remote Sens. 37: 138-149. https://doi.org/10.1080/21507 04x.2015.1126375

Qi, J. Chehbouni, A. L. Huete, A. R. Kerr, Y. H. Sorooshian, S., 1994: A modified soil adjusted vegetation index (MSAVI). Remote Sens. Environ. 48: 119-126. https:// doi.org/10.1016/0034-4257(94)90134-1

Rouse, J. W., Haas, R. H., Schell, J. A., Deering, D. W., 1973: Monitoring vegetation systems in the Great Plains with ERTS. In: Third ERTS Symposium. NASA, 309-317.

Sabogal, C., Besacier, C., McGuire, D., 2015: Forest and landscape restoration: concepts, approaches and challenges for implementation. Unasylva 66(245): 3-7.

Selvam, V., Ravichandran, K. K., Gnanappazham, L., Navamuniyammal, M., 2003: Assessment of community-based restoration of Pichavaram mangrove wetland using remote sensing data. Curr. Sci. 794-798.

Simard, M., Riel, B. V., Denbina, M., Hensley, S., 2016: Radiometric Correction of Airborne Radar Images over Forested Terrain with Topography. IEEET Geosci Remote 54(8): 4488-4500. https://doi.org/10.1109/ TGRS.2016.2543142

Shimu, S. A., Aktar, M., Afjal, M. I., Nitu, A. M., Uddin, M. P., Al Mamun, M., 2019: NDVI Based Change Detection in Sundarban Mangrove Forest Using Remote Sensing Data. In 2019 4th International Conference on Electrical Information and Communication Technology (EICT), pp. 1-5. https://doi.org/10.1109/EICT48899.2019.9068819

Sowmya, D. R., Shenoy, P. D., Venugopal, K. R., 2017: Remote Sensing Satellite Image Processing Techniques for Image Classification: A Comprehensive Survey. Int. J. Comput. Appl. Eng. Sci. 161(11): 24-37. 
Suding, K., Higgs, E., Palmer, M., Suding, K., Higgs, E., Palmer, M., Callicott, J.B., Anderson, C.B., Baker, M., Gutrich, J. J., Hondula, K. L., LaFevor, M. C., Larson, B. M., Randall, A., 2015: Committing to ecological restoration. Science 348: 638-640. https://doi.org/10.1126/science. aaa4216

Ünsalan, C., Boyer, K. L., 2004: Classifying land development in high-resolution panchromatic satellite images using straight-line Statistics. IEEE T Geosci Remote. 42(4): 907-919.

Van Den Bergh, F., Wessels, K. J., Miteff, S., Van Zyl, T. L., Gazendam, A. D., Bachoo, A. K., 2012: Hitempo: a platform for time-series analysis of remote-sensing satellite data in a high-performance computing environment. Int. J. Remote Sens. 33(15): 4720-4740. https://doi.org/10.1109/ TGRS.2003.818835

Van Leeuwen, W. J., Orr, B. J., Marsh, S. E., Herrmann, S. M., 2006: Multi-sensor NDVI data continuity: Uncertainties and implications for vegetation monitoring applications. Remote Sens. Environ. 100(1): 67-81. https://doi. org/10.1016/j.rse.2005.10.002

Wang, F., An, P., Huang, C., Zhang, Z., Hao, J., 2018: Is afforestation-induced land use change the main contributor to vegetation dynamics in the semiarid region of North China? Ecol. Indic. 88: 282-291. https://doi.org/10.1016/j. ecolid.2017.12.061.

Wilson, E. H., Sader, S. A., 2002: Detection of forest harvest type using multiple dates of Landsat TM imagery. Remote Sens. Environ. 80(3): 385-396. https://doi. org/10.1016/S0034-4257(01)00318-2
WWF, 2016: Third Party Monitoring of The Billion Trees Afforestation Project in Khyber Pakhtunkhwa Pakistan, World Wide Fund for Nature Pakistan. Available at: https://d2ouvy59p0dg6k.cloudfront.net/downloads/bttap_third_party_monitoring_report_1.pdf

WWF, 2017: Third Party Monitoring of The Billion Trees Afforestation Project in Khyber Pakhtunkhwa Pakistan, World Wide Fund for Nature Pakistan. Available at: https://d2ouvy59p0dg6k.cloudfront.net/downloads/ btap_monitoring_report_phase_ii.pdf

Zahid, D. M., Shah, F. U. R., Majeed, A., 2010: Planting Eucalyptus camaldulensis in arid environment-is it useful species under water deficit system. Pak. J. Bot. 42(3): 1733-1744.

Zahid, D. M., Ahmad, R., 2016: Effect of age of Farmgrown Eucalyptus on seasoning quality of wood and its utilization in Pakistan. Int. J. Agric. Biol. 4: 315-317.

Zahid, D. M., Nawaz, A. A. M., 2007: Comparative water use efficiency of Eucalyptus camaldulensis versus Dalbergiasissoo in Pakistan. Int. J. Agric. Biol. 9: 540-544.

Zhu, Z., Woodcock, C. E., 2014: Continuous change detection and classification of land cover using all available Landsat data. Remote Sens. Environ. 144: 152-171. https:// doi.org/10.1016/j.rse.2014.01.011

Zhumanova, M., Mönnig, C., Hergarten, C., Darr, D., Wrage-Mönnig, N., 2018: Assessment of vegetation degradation in mountainous pastures of the Western Tien-Shan, Kyrgyzstan, using eMODIS NDVI. Ecological indicators 95: 527-543. https://doi.org/10.1016/j.ecolind.2018.07.060 


\section{Sažetak}

\section{Projekt pošumljavanja Pakistana s milijardu stabala - praćenje pomoću snimaka s Landsat-8}

U skladu s obvezama koje je pokrenuo Bonn Challenge, Pakistan je (pokrajina Khyber Pukhtunkhwa) proveo obnovu šuma i pošumljavanje na 0,35 milijuna hektara između 2015. i 2017. godine. Projekt sadnje milijardu stabala (Billion Tree Aforestation Project - BTAP) inicijativa je masovnoga pošumljavanja i obnove šuma kako bi se ispunila obveza prema dogovoru Bonn Challenge. Trenutačna je studija pilot-projekt za procjenu uspješnosti plantažnih aktivnosti provjerom regeneracije, učinka rasta i stope preživljavanja plantaža podignutih u okviru projekta BTAP u šumskoj regiji Malakand. Četiri vegetacijska indeksa izračunata su sa slika dobivenih s Landsat-8. Oni uključuju normalizirani vegetacijski indeks razlika (NDVI), vegetacijski indeks prilagođen tlu (SAVI), modificirani indeks vegetacije prilagođen tlu (MSAVI) $i$ indeks razlike vegetacije (DVI). Ukupno 72 uzorkovane parcele veličine 0,1 ha postavljene su na 11 plantaža koje se protežu na 647 ha površine u područjima Timargara, Chakdara i Jandool. Rezultati su pokazali da su sva odabrana plantažna mjesta dala dobre rezultate u pogledu stope preživljavanja, koje se kreće uglavnom iznad $90 \%$. U sastavu vrsta najveći udio ima Eucalyptus camaldulensis - 81\%, zatim Robinia pseduacacia sa $17 \%$ i Pinus roxburghii s $2 \%$ udjela u nasadu. Učinak rasta bio je dobar u svih vrsta; Pinus roxburghii postigao je prosječni opseg od 14,3 cm i visinu od 0,98 m, dok su Eucalyptus camaldulensis i Robinia pseudoacacia postigle prosječni opseg od 10,3 cm odnosno 12,1 cm s 2,62 $\mathrm{m}$ odnosno 2,50 m visine u 27 mjeseci. Nadalje, u pogledu korelacije između obujma $\left(\mathrm{m}^{3}\right)$ i spektralnih vrijednosti snimaka s Landsat-8 uočeni su dobri odnosi. Najveći učinak $\left(R^{2}=0,63\right)$ zabilježili su NDVI i SAVI. Vremenske promjene spektralnih vrijednosti snimaka dobivenih s Landsat-8 od 2013. do 2018. godine pokazale su da je plantaža bila uspješna na tim mjestima. Studija je zaključila da će aktivnosti FLR u pokrajini Khyber Pukhtunkwa rehabilitirati i poboljšati postojeće šumske ekosustave i podržati lokalni život za ublažavanje klimatskih promjena.

Ključne riječi: milijarda stabala, projekt pošumljavanja, prihvat sadnica, prirast, Landsat-8

Received (Primljeno): April 23, 2021.

Accepted (Prihvaćeno): June 24, 2021.
Authors' addresses - Adrese autorâ:

Muhammad Daud Khan

Anwar Ali

Pakistan Forest Institute

Forest Education Division

Peshawar

PAKISTAN

Arif Iqbal

Zia-ur-Rehman*

e-mail: naveedahmad795@gmail.com

Waqar Ahmed

Saba Ali Arooj

PMAS Arid Agriculture University

Department of Forestry and Range Management

Rawalpindi

PAKISTAN

${ }^{*}$ Corresponding author - Glavni autor 